\title{
Utopian resort living: Islands of reclamation and environmental resistance in Bali and Western Australia
}

By Thor Kerr at Curtin University and Agung Wardana at Universitas Gajah Mada

\begin{abstract}
This article provides a comparative analysis of localized contests over the reclamation of new islands for resort-style development projects in waters near tourist destinations in Bali and Western Australia. The research focuses on the Tirta Wahana Bali Internasional Resort proposed for a seabed site in Benoa Bay, Bali, and the North Port Quay development proposed for a seabed site off the coast of Fremantle, Western Australia. The investigation finds that proximity plays a common critical role in the shaping of discourses, environmental alliances and planning determinations around the resort-island reclamation projects. Representations of the proposed new islands stimulated local community resistance movements because the projects reflected the utopian desires of their developers to create resort lifestyle communities that were geographically near yet socially far from people already enjoying the coastal waters targeted for reclamation. By comparing discourses around the two projects, we identify how the artful reimagining of environmental and cultural heritage within each of the resistance movements has influenced local politics and created opportunities for bringing Indigenous perspectives into public view to unsettle nationalist and colonial nativist views of lands and waters in tourist areas.
\end{abstract}

Keywords: resort island; utopias; environmental discourse; Benoa Bay; Fremantle

In 2015, the Ubud Readers and Writers Festival ${ }^{1}$ cancelled a panel due to discuss community responses to resort island reclamation projects in Benoa Bay, Bali, and in waters off the coast of Perth, Western Australia (Groves, 2015). The ForBali panel was cancelled a day after festival organizers gave in to police pressure by cancelling three panels on books giving voice to survivors of the 1965 anti-communist purges that had devastated communities in Bali and other regions of Indonesia. The link from the 
banning of panels discussing Indonesian New Order atrocities from half a century ago to a panel discussing contemporary forms of resistance to resort reclamation projects was unclear to many of the thousands of visitors at the festival. Through this article, links between past experiences and contemporary tensions are examined in the two reclaimed-island development cases that would have been discussed at the international writers festival had the ForBali panel not been censored. The first case examined here is the Tirta Wahana Bali Internasional (TWBI) resort plan for new islands to be reclaimed in Benoa Bay, near Bali's international airport. The second case is the North Port Quay (NPQ) plan for new islands to be reclaimed off the coast of Perth, Western Australia. Both projects were resisted and successfully stalled through the artful expressions of people living near the proposed project sites. This article compares the contexts of TWBI and NPQ and how they were resisted despite their developers' substantial resources. The objective of this research is to compare discourses around these mega resort projects, to identify commonalities in how the projects were promoted and resisted, and to understand how controversies around these projects have impacted local politics and culture.

\section{Approaching artificial islands}

Our examination of controversies around TWBI and NPQ is informed, particularly, by scholarship on the history of social struggles around coastal development projects in these projects' local contexts (Warren, 2012; Kerr, 2015); on radical departures from normal planning processes due to environmental risks (Kenworthy, 2006; Warren \& Wardana, 2018), and on the traditional yet repetitive utopian desire (Eco, 2015) to be usefully near but socially disconnected from on-shore communities (Miéville, 2016). To understand the intensity of localized public reactions to news of TWBI and NPQ, the segregated space of artificial islands is approached as a utopian construction functioning 
as 'an isolated, coherently organized, and largely closed-space economy' in which relations with the outside world are closely monitored (Harvey, 2000, p. 160). Utopia, in this sense, is the proposed world of spatial play within which the dialectics of social change are repressed to ensure social stability through fixed spatial configuration. This article examines how two of these utopian-island worlds were promoted by developers and, ultimately, resisted by local communities.

This examination involved an analysis of the corpora of two hundred public and media texts gathered on the NPQ case and related events between 2008 and 2018 and a hundred public and media texts gathered on TWBI between 2013 and 2018. The analysis was informed by visits to sites and public events, verification interviews and desk research on spatial-rights issues in Bali and Western Australia in fields of urban planning, environmental law, cultural studies and media studies.

\section{Benoa Bay: the islands of Tirta Wahana Bali Internasional}

Bali is the most popular tourist destination in Indonesia. Annually, Bali receives 3 to 4 million tourists with future projections of up to 7 million, twice its population. After the shameful wars of puputan (until the end), Dutch colonists created Bali's tourism industry and its 'island of paradise' brand (Vickers, 2012). This brand is the first and most powerful construction of utopianism in modern Balinese history as the colonial administration responded to the messiness of its colonised regions by segregating the island culturally and politically from the 'otherness' of Java. The utopian brand, 'the island of paradise', has persisted throughout post-colonial eras in which Balinese society is imagined by tourists and through which Balinese reflect their cultural identity. 
policy focussed on Bali as the nation's centre of mass tourism development. With financial deregulation, investments in hotels, golf courses, resort complexes and other tourism developments flocked to the island (Warren, 1998). Benoa Bay, the semienclosed waters of Bali's southern peninsula, was no exception. In the early 1990s mega projects with luxury resorts were developed in the bay by Bali Turtle Island Development (BTID) and Bali Benoa Marina (BBM); both owned by Suharto's sons (Aditjondro, 1995). Following the economic and political crises that ended Suharto's presidency, BBM was aborted yet the bay's mouth was dredged to reclaim additional land for Serangan Island in the first stage of BTID's construction (Warren \& Wardana, 2018).

Over the last twenty years, the Serangan Island reclamation has had a severe impact on Bali's southern coastline. The mouth of Benoa Bay has narrowed, altering water circulation in the bay. Studies have concluded that the bay is heavily polluted and faces coastal erosion and sedimentation, threatening the existence of surrounding mangrove forests (PEMSEA \& Bali PMO, 2004; Putra, 2009). In 2011, the community of Tanjung Benoa on the south-eastern side of the bay submitted a proposal to government seeking assistance to rehabilitate the southeast coast from severe erosion. The government has not responded, citing financial and expertise constraints. It seemed to consider private enterprises capable of addressing the situation through their financial capacity and expertise in creating added value while conserving the bay, thereby bringing revenue for government and jobs for local communities, instead of it being a government expense (Wardana, 2019).

In late 2012, the provincial government granted a permit to Tirta Wahana Bali Internasional (TWBI) to undertake a 'revitalisation' project in Benoa Bay and to develop the bay into a new tourist site. The company is owned by Tomy Winata, a 
tycoon known as the Armed Forces banker during Suharto's New Order. TWBI inherited, and aims to expand BBM's utopian project to develop artificial islands in Benoa Bay. While Tommy Suharto's BBM proposed constructing a 270-hectare artificial island through reclamation, Tomy Winata's TWBI includes the construction of a dozen islands covering up to 700 hectares of the bay (Warren \& Wardana, 2018). TWBI includes a resort complex, theme parks, botanical gardens, eco-tourism sites, cultural exhibition arenas, residential areas, hospitals as well as a university. Engaging with Bali's tourist attractions from its location near Ngurah Rai International Airport and Benoa Port, Winata's resort complex is imagined as a global village connected with other global urban nodes.

In its marketing, TWBI adopts environmental discourse claiming the project is urgently needed to fix the bay's severe sedimentation. Once the bay is revitalised and artificial islands reclaimed for resort complexes, Tirta Wahana Bali Internasional (2014) pledged 40 percent of all reclaimed land for green and open spaces, such as botanical and eco-tourism sites. The company would undertake conservation programs to protect the bay's waters and mangrove forest from degradation. Hence, the government need not spend anything conserving bay areas while looking forward to revenues from the bay's utilisation.

In Bali, the construction of tourist resort complexes detached from local conditions is not a new phenomenon. In the early 1970s, when the Indonesian Government began facilitating mass tourism, the French-based consulting company SCETO proposed concentrating tourist facilities in the southern peninsula of Nusa Dua on unproductive agricultural land relatively far from the provincial capital, Denpasar. SCETO considered this tourist enclave might minimise or prevent impacts of tourism on Balinese culture, especially contamination from Western values because Balinese 
culture was considered a key competitive advantage for the industry. The planners saw Balinese culture as fragile and threatened by outside forces, echoing the Dutch Colonial ethical policy of Baliseenering (Balinesation) - a colonial ideal of 'Balinese-ness' introduced to protect Balinese culture from waves of nationalism, Islamism and communism from neighbouring Java by making Balinese proud of themselves (Schulte Nordholt, 2000).

A decade after SCETO's plan, however, tourist areas expanded from 15 in 1988 to 21 in 1993, covering around 24.7\% of the province (Picard, 1996). Almost all aspects of Balinese life were penetrated by tourism creating 'touristic culture', a condition where Balinese internalised their cultural identity and their cultural/religious practices became spectacles for tourist consumption (1996). Yet, Balinese culture does not serve merely as a spectacle for tourism, it can also be weaponized in challenging development projects seen to harm local livelihoods and the environment (Wardana, 2019).

Moreover, intensive encounters between local communities and tourism have had both positive and negative impacts. In the context of Ubud Village, for instance, MacRae (2016) observed Balinese embracing cosmopolitanism through their cultural engagements with foreigners. However, in other parts of Bali, such encounters have resulted in unpleasant social changes for the tourist industry. A recent trend shows increasing incidents of crimes targeting and/or involving foreigners (Cassrels, 2014). International, national and local mass media as well as social media have frequently reported and exposed worsening environmental conditions and dishonest and unfriendly practices by locals toward foreigners. For example, Marshall (2011) in Time magazine characterises Bali tourism as 'holidays in hell', and Thierman (2013) in Huffington Post describes the island becoming a 'paradise lost'. 
Bali seems to be regarded by observers as no longer reflecting what travel brochures have said and promoted about it. In response, the tourism industry has been adjusting its models of development. Since the early 2000s, for instance, semi-private villas with a private swimming pool and guards have become popular across the island for providing a sense of security and private leisure compared to hotels and other mass accommodation. The expansion of villas has partly caused an increase in the demand of land and, in turn, the rate of land conversion. Annually 1,000 hectares of agricultural land is converted into tourism facilities including villas (MacRae, 2005; Warren, 2009). As demand for land rises, so too has the price of land and its associated tax. These conditions represent what Minca (2000, p. 390) calls the 'mature exotic' resulting in 'a substantial deterioration in the relationship between the local population and the tourist masses, due to mutual disenchantment, unfulfilled expectations and misunderstandings, as well as to the challenges posed to the social fabric of the host communities.'

The development of a tourist enclave through reclamation in Benoa Bay should be seen in this wider context. Unlike in the early 1970s when the enclave was developed to preserve Balinese culture, the development pursued by TWBI would serve different objectives. Firstly, the construction of artificial islands by the company is positioned as a solution to the high rate of agricultural land conversion. As a marketing strategy, the company presents public concern over the conversion of agricultural land as threatening the existence of Bali's traditional subak of system of irrigation and social organization recognised by the UNESCO World Heritage Convention. Secondly, reclamation is more economical. Constructing 700 hectares of artificial islands in Benoa Bay is cheaper than procuring land for a similar resort on Bali's mainland. A hectare of land in Bali's southern peninsula costs around IDR100 billion (USD5.5 million); to buy and 
consolidate 700 hectares the company would need IDR70 trillion (USD4.6 billion) ${ }^{1}$ not including the costs of permits, site preparation and operations. Meanwhile, TWBI estimates that reclaiming and preparing land for the project in the waters of Benoa Bay would cost around IDR30 trillion (USD2 billion); saving the company USD2.6 billion.

Thirdly, the resort enclave would enable more adequate mechanisms of control. Bali has twice experienced major terrorist attacks. It has also been threatened by the spread of infectious diseases and high rates of HIV/AIDS, by crimes and disturbances, as well as gangster rivalry. Physically segregating artificial islands from the mainland would enable developer surveillance and control of what can or cannot be done in the resort by quarantining it from the complex Balinese dynamics of social change onshore. Finally, the mechanism of control and surveillance would enable the company to reinvent and simulate the 'ideal' construction of Bali in accordance to tourists' expectations. Here, Bali as a 'brand' (Hobart, 2011) remains handy for global marketing. TWBI calculates that investing capital in Bali's tourism industry remains profitable provided it can meet tourists' expectations, especially in experiencing 'authentic' Balinese culture. By constructing a segregated space for its tourist enclave, TWBI aims to protect tourist expectations from the messiness of local social dynamics. What is considered 'authentic' Balinese culture in travel media would be reinvented, stimulated and concentrated within the utopian resort enclave to fulfil tourists' expectations without necessarily encountering the local population (Wardana, 2019).

\section{Fremantle: The islands of North Port Quay}

Fremantle receives over a quarter of a million overnight visitors annually. Only 62,000

\footnotetext{
${ }^{1}$ USD1 $=$ IDR 15,182
} 
of them are from overseas (Tourism WA - Strategy and Research, 2018), but they stay much longer than domestic visitors, and make up more than half of the 1.4 million visitor nights in Fremantle. In waterfront planning, state and municipal governments have presumed Fremantle to be 'a world-class tourist destination' (MacBeth, Selwood $\&$ Veitch, 2012, p. 178). Since the 1970s, Fremantle has been transformed from the decaying port town of metropolitan Perth into a tourist destination due to government and private investment in tourism, visitor and heritage projects amid broad international changes in gentrification, de-industrialization and port technology. This transformation to an upmarket tourist destination was boosted by the world-heritage listing of Fremantle prison (UNESCO, 2010) and the arrival of 2,000 journalists for the America's Cup yacht race in 1986-1987 (Hartley, 1988). Besides leisure craft, tourist ferries and cruise ships, Fremantle hosts a major port through which containers and motor vehicles are imported, and scrap metal, livestock (Westport, 2018) and minerals are exported. Fremantle Society was established in 1972 to protect the city's colonial built environment and other cultural heritage. The society, supported by the National Trust, imagined Fremantle to be 'the Port City at the mouth of the Swan River in the Western most State of Australia' (Fremantle Society, n.d.). This imagining helped to turn downtown Fremantle into a tourist museum of neo-classical facades that overwrite Indigenous representations of the area (Kerr, 2015). Yet, Whadjuk Noongar have lived in the Walyalup area for up to 50,000 years (Moodjar Consultancy, 2016). Until the spiritually-significant sandbar ${ }^{2}$ was blasted open for Fremantle port, this was one of just two places for fording the Derbal Yaragan (Swan River). Walyalup is a sacred place for funeral rites that help people's spirits to cross the Wardan (sea) to Wadjemup (Rottnest Island), and it became a sad place when thousands of Noongar and other Indigenous men were shipped from Walyalup to colonial exile and death on Rottnest. 
Coastal development disputes around Fremantle tend to reference both the colonizing and decolonizing narratives of Australia (Hage, 2003), as beaches are defended for 'native-ized territoriality' (Perera, 2009, p. 150) and heritage places for environmentalist-indigenous alliances (Neale \& Vincent, 2016). Embodying this tension, the Save Freo Beaches Alliance demonstrated its strength in January 2008 when 2,500 people gathered for a fundraiser by the beach (Kerr, 2015). Developers have tried to head off such activist challenges while meeting consumer demand for premium beach-front properties by featuring ecological modernization technologies and slogans in their advertising. However, developers' attempts to produce a clean, green image coincided with growing public awareness of unethical practices by property developers seeking governmental approval for coastal projects. Western Australia's Corruption and Crime Commission (2008) investigated allegations of local council manipulation by coastal developers, and its hearings in 2007 generated much media attention. Growing awareness of transgression in the privatization of coastal land lent legitimacy to local organizations resisting developers around Fremantle, and provided electoral support for politicians campaigning against resort-style property development (D’Anger, 2008).

North Port Quay was launched in May 2008 as a USD7 billion² 'plan to build six islands across 345 ha of seabed in Fremantle's North Quay, including houses, offices, hotels and schools' (Hatch, 2008, p. 3). The development consortium was led by Greg Poland's Strzelecki Group (2009), known for developing residential marina resorts to the north and south of Fremantle. The Strzelecki-led consortium sought local demonstrations of support for its planning negotiations with the state government and Fremantle Ports, particularly after images of NPQ's primary lobbyist were published

\footnotetext{
${ }^{2} \mathrm{USD} 1=\mathrm{AUD} 1.40$
} 
alongside images of other lobbyists caught up in the Corruption and Crime Commission's coastal development investigations (Taylor, 2008). While NPQ's Project Director set out to win over Fremantle through public consultation, its master planner promised to "practice the kind of community building our forebears practised in the 1800s' (Hatch, 2008, p. 3). These colonial practices were read negatively in Fremantle, despite the dominant erasure and overwriting of Indigenous culture and community since Captain Fremantle arrived with colonists and built the Round House fort. This cliff-top jail has become a popular tourist attraction, also serving as a place of healing during the first One Day Festival in 2017 when Noongar elders held a smoking ceremony recognizing its role in genocidal shipping of their people (Cox \& Kerr, 2018) to a concentration camp on Rottnest Island (Mickler, 1990).

In promoting NPQ, Poland attempted to articulate a greater good by recruiting a local university professor as an environmental sustainability consultant and spokesman for the project. In response, sustainability professors at other universities argued that NPQ would be an environmental catastrophe because of its impact on local beaches and substantial carbon emissions from the unnecessary reclamation of islands from seabed. NPQ responded with an expensive advertising campaign that foregrounded the project's environmental and economic benefits, that it 'has the potential to be the most sustainable residential, marina, recreational and tourism development in the world' (North Port Quay, 2008a). However, opposition emerged immediately within intense media coverage. Western Australia's Premier, Alan Carpenter, opposed the project as did its subsequent Premier, Colin Barnett. On the beach in his electorate of Cottesloe, overlooking the NPQ site, Barnett performed a populist stance against NPQ. He soon regained control of the Liberal Party and became Western Australia's Premier in late 2008. Meanwhile, the consortium distributed DVDs, pamphlets and links to a website 
claiming that NPQ could 'be the most popular tourist destination in Western Australia, attracting up to 10 million visitations a year' (North Port Quay, n.d.). Legitimization of NPQ became a struggle for common-sense acceptance in Fremantle, played out in local media and political campaigns across three elections. The consortium sought legitimacy by associating its project with sustainability - NPQ 'could become the world's first carbon-free development' (North Port Quay, 2008b, p. 7) - and focussed its advertising and public relations resources on election campaigns. Yet, its attempts to claim the environmental high ground failed in discursive encounters in Fremantle. The ecological risk of a carbon-constrained future articulated by NPQ's proponents was transformed into the ecological risk of the project's construction, and its investment in 'Fremantle's future' was read as an unacceptable development risk by many. The threat of NPQ became a discursive tool, used effectively by a Greens party politician to win the seat of Fremantle in state parliament in 2009, ending 85 years of Labor Party representation and heralding transformation in Fremantle's culture.

Meanwhile, Fremantle Council debated a motion to oppose NPQ and resolved to have its planning committee make a report on the project in the lead up to the municipal election. Councillor Brad Pettitt, a sustainability professor who had argued consistently against the environmental credibility of NPQ, ran for mayor. Pettitt offered an alternative green city concept that included an appreciation of Fremantle's existing built environment and protection of its economic and social heritage. The campaign focussed on inclusion in local democratic decision making against a backdrop of the threat of NPQ and planning authorization being shifted from municipal councils to state planning boards. Fremantle Council adopted its planning committee's recommendation to reject NPQ. Then Pettitt won the mayoral election in late 2009, ending tenable representation of local support for NPQ and its legitimacy as an environmental solution. 
Although Indigenous concerns about NPQ were rarely reported in mainstream media, the emergence of an environmentally progressive council surfing a wave of reaction against the project has provided opportunities for Indigenous voices to be heard. The council began a long process of working through perverse colonial regulations in 2010 to engage Whadjuk people in land-use determinations at sacred sites along the Derbal Yerrigan in Fremantle (Moodjar, 2016). The strength of this collaboration was demonstrated in late 2016 when the council defied threats from the Australian government and the wrath of mainstream media by deciding to replace Fremantle's Australia Day beachfront fireworks - which celebrated Australia's first colonial settlement - with an inclusive One Day Festival a few days later. Indigenous spokespeople, journalists and media organizations engaged with Mayor Pettitt and Fremantle's progressive councillors in helping to persuade the broader public that Australia Day celebrations harmed Indigenous people and that there were more inclusive and artistic ways to celebrate community (Cox \& Kerr, 2018).

Local political change did not, however, prevent the subsequent dredging of Fremantle's inner-harbour to reclaim 27 hectares of land from seabed at the NPQ site, angering the Waugal spirit of the Whadjuk Noongar People (Moodjar Consultancy, 2016). Truck parking lots, a service station and convenience store have been built at the site, marking its use for logistics (Fremantle Ports, 2013). Since 2014, real-estate prices have collapsed in metropolitan Perth and the economic imperative for land reclamation has shifted from marina resort development towards the reclamation of beaches and wetlands for import-export infrastructure, particularly toll roads and logistics hubs. Some proposed projects within this shift have been overcome by local community resistance, including a freight tollway that would cut through wetlands, bushland and neighbourhoods on route to Fremantle (Whish-Wilson, 2017). This resistance saw 200 
people arrested for preventing excavation machinery cutting through a Noongar dreaming trail and cherished wetlands (Kerr, 2017). As the demonstrators faced prosecution, Barnett's government was routed in the March 2017 state election. The new Labor government terminated the road project, and developed a waterfront scheme that encourages tourist-oriented development in the vicinity (Westport, 2018) of the NPQ site.

\section{Proximity in environmental arguments and policy making}

Spatial and temporal proximity played an important role in community and governmental responses to the TWBI and NPQ projects. The following sections describe how representations of the new-island resort developments stimulated localized community resistance because they were often read as destructive impositions that threatened people's affective and economic investments in nearby cultural and environmental objects. Failing to find sustained, tenable, support from local communities, TWBI's and NPQ's proponents looked further afield for evidence and supporters to back their arguments that future economic and environmental benefits would accrue from the new island developments. Yet, the further into the spatial and temporal distance they looked for support, the more these projects implied the developers' desire to build new ideal communities isolated from existing communities. By analysing the dynamics of proximity in representations of TWBI and NPQ, we can begin to understand how the reimagining of environmental and cultural heritage within their respective resistance movements has influenced local politics and created opportunities for Indigenous perspectives to emerge in public discourse. 


\section{The public contest over Tirta Wahana Bali International}

In Benoa Bay, the Tanjung Benoa community initially supported Tommy Winata's program that articulated local aspirations to rehabilitate the coastline. TWBI's corporate social responsibility approach aggressively sought 'social license' from Tanjung Benoa villagers, whose interests would be affected by the project.

Such support turned into resistance once mass media revealed TWBI's plan to reclaim massive water areas of the bay to build resort complexes and alter the small island of Pulau Pudut. Situated administratively in Tanjung Benoa, Pudut holds important symbolic value for locals with its community temple and turtle conservation site. For villagers whose local economy depends heavily on water sport services and fisheries, the bay water areas are common resources to be utilised by them and other communities surrounding the bay. Enclosure of the bay's waters for exclusive resort development by TWBI would threaten local economic and socio-cultural conditions. The reclamation plan stirred collective memory of the severe impacts of reclamation at Serangan Island twenty years earlier.

Assisted by NGOs, student activists and artists under the banner of the Balinese Forum Against Reclamation (ForBali), the local community surrounding the bay organised themselves into a resistance, the scale of which has been unprecedented in the post authoritarian era of Bali. Their rejections of the project, initially, relied on legal and technical reasoning. Opponent groups found legal flaws in the permit granted by the Governor of Bali, Made Mangku Pastika, citing a violation of higher laws and regulations dealing with spatial planning of the bay areas as well as the legality of undertaking reclamation within the bay. Both Spatial Planning Regulation for Bali Province No. 16/2009 and Presidential Decision No. 45/2011 concerning the Spatial Planning for the Sarbagita Metropolitan Region have designated the bay, including its surrounding mangrove forest, a water conservation area. Also, Presidential Decision 
No. 122/2012 concerning Reclamation in the Coastal and Small Islands prohibits reclamation within a water conservation area (Wardana, 2018). Technically, opponent groups utilised modelling by Conservation International predicting the impacts of Benoa Bay reclamation on the coastal areas of the bay to show how Winata's project would damage their livelihood (Sudiarta et al., 2013).

TWBI mobilised its resources to counter the opponent groups' arguments. Due to its strong network of government officials including then Indonesian President Susilo Bambang Yudhoyono (SBY), TWBI's interests were advanced in government development plans. Provincially, TWBI's project was included in Bali's midterm development plan while, nationally, it became a strategic project in the Master Plan of Indonesian Economic Expansion and Acceleration (MP3EI). At the end of his term in office, President SBY even revised Presidential Decision No. 45/2011 as Presidential Decision No. 51/2014 to downgrade the status of Benoa Bay from a water conservation area to a general utilisation area. The conservation area that once covered all waters in the bay now only covers the mangrove forests, leaving the waters open for development activities. Consequently, the Presidential Decision prohibiting coastal and small island reclamation in a water conservation area no longer applies to the waters of Benoa Bay (Wardana, 2018).

On technical arguments, TWBI is almost untouchable because it can afford to hire technocrats and use prominent universities as its mouthpiece. TWBI hired Udayana University in Bali to conduct a feasibility study, but under mounting pressure from opponent groups and local media, especially Bali Post, Udayana eventually concluded that the project was not technically, economically or socio-culturally feasible. But prior to TWBI becoming a public controversy, Udayana researchers involved in the study had shown strong support for the project, claiming it was 'feasible with conditionality' 
(layak bersyarat). Dissatisfied with the results of Udayana's study, TWBI hired prominent Indonesian state universities in Java including Bandung Institute of Technology (ITB) and Bogor Institute of Agriculture (IPB). Experts were mobilised to counter opponent groups who claimed that the project would have severe impacts on the environment - especially coastal erosion and flooding - and local livelihoods. A professor of marine and coastal biology from IPB, countered such claims by stating in national media that TWBI's 'revitalisation' project was urgently required to solve conditions of severe sedimentation in the bay which may affect Pulau Pudut and the mangroves (Latif, 2014).

The term 'revitalisation' was used by TWBI not without reasoning. First, it claims the project follows a 'green development' concept of making profit from revitalised or rehabilitated areas of the bay which have been degraded. Secondly, 'revitalisasi' (revitalisation) is presumed as a psychologically neutral term that enables proponents to avoid uttering 'reklamasi' (reclamation), which might recall negative memories of BTID’s Serangan Island reclamation project. Finally, from a legal viewpoint, the term 'revitalisasi' was recognised by Presidential Decision No. 45/2011 in relation to the spatial planning of the Sarbagita Metropolitan Region where the bay is situated. In the decision, 'revitalisasi' is pursued as one of the government's strategic agendas for protecting functions of the bay areas. This is affirmed by Presidential Decision No. 51/2014 which stipulates that revitalisation of Benoa Bay must be implemented as a government priority (Wardana, 2019).

Losing ground on legal and technical arguments, opposition groups turned to adat (traditional) and religious laws as a 'legal engineering' strategy (Wardana, 2018). The groups started by identifying sacred sites within the bay and found that around 70 sacred sites could be 'polluted' spiritually by Winata's project (Suastha, 2016). They 
then employed the 1994 Bhisama (religious ruling) of the Hindu Dharma Organisation (PHDI) concerning the sanctity radius of temples and sacred spaces to show how TWBI would violate their sanctity. Based on the Bhisama, adat communities surrounding the bay declared Benoa Bay a sacred space in which utilisation for tourist resorts may affect the spiritual balance of the bay. The adat communities have an authoritative position in socio-cultural arguments, creating problems for TWBI's navigation of the Environmental Impact Assessment (AMDAL) process. The adat response to TWBI was made public through series of cultural parades (parade budaya) in collaboration with ForBali where artistic or cultural performance took place on the street, as well as through adat rituals at the village levels to enhance local solidarity.

\section{The public contest over North Port Quay}

In Fremantle, nobody disputed it would be cheaper to reclaim 345 hectares of land at sea than buy up beachfront land for NPQ. Yet, proponents underestimated the political cost of attempting to overcome local people's desire to defend coastal places. This desire and its entanglements within dominant cultural logic meant that every promotional push to represent NPQ as a scientific, economic or even a parochial solution to a problem was met with overwhelming resistance within the local public. The consortium directed its requests for planning approval to the Western Australian government, rather than Fremantle Council, and headlined its advertisements: 'Why can't Western Australia lead the world in sustainable development?' (North Port Quay, 2008b, p. 7). However, in an election year, leaders of the Labor government and Liberal opposition did not heed the consortium's call to participate in NPQ's global contest. The consortium then had no choice but to seek support at the municipal level where local understandings of environmental threat played a powerful role in shaping public conversation about NPQ. The consortium advertised to people in Fremantle that NPQ 
would be a sustainable development, but its advertised images were not read as intended. Instead, renderings of a sea wall around NPQ reminded locals of rising sea levels without offering them protection from inundation. Locals saw themselves outside NPQ's walls enduring rising sea levels aggravated by carbon emissions and other environmental damage from its construction. Meanwhile, arguments that NPQ would mitigate a future global threat of climate change were ineffective because climate change was already sensed locally. With promises of research scholarships to study NPQ’s sustainability, Greg Poland had recruited the head of Curtin University’s Sustainability Policy Institute as NPQ's key environmental spokesperson. In the media, the professor presented ecological modernization solutions that could make NPQ carbon neutral in future. Yet, sustainability professors from other local universities countered that NPQ would emit excessive carbon emissions in the meantime due to island reclamation. Climate change was real to proponents and opponents of NPQ but, for many in Fremantle, it was more motivating as a spatially and temporally immediate threat than the globally distant threat suggested by NPQ's environmental spokesperson. This power of proximity came from objects in the local environment being sensed more intimately than an abstract global environment. Threats from NPQ to sensual experiences associated with local beaches, buildings, etc. undermined the consortium's attempts to define environmental threats as future global problems. Community resistance to the project was successful because the dominant environmental problem associated with the project shifted rapidly in public conversation from proponents' description of long-term global ecological threats to opponents' talk of the project immediately threatening their local environment, where beach aesthetics were a powerful trigger for collective action. People were moved by an immediate call to defend the beach, rather than an advertised low-carbon, island community. Standing for 
'our beaches' was mobilized artfully and successfully as an empty signifier unifying popular resentment (Laclau, 2005) against NPQ because it engaged desire for repeat sensual experience of the local environment, albeit within a dominant nationalist narrative. The localized popular movement that blocked NPQ emerged from a shared, deeply conservative response to the radical imposition of a utopian resort development, disguised poorly as an environmental solution to climate change.

\section{Utopia and its discontents}

The TWBI and NPQ cases can be read, in the lens of David Harvey (2000), as repeated instances of apparently globalised free-market utopianism colliding with localised spatial utopianism. The project developers promised billions of dollars would be invested in their sustainable resort islands in popular tourist areas. Tomy Winata's and Greg Poland's utopias were planned to capture market demand for resort living in tourist destinations in island spaces of capital accumulation quarantined from the complexities, traumatic histories and environmental experiences of their local communities. The two cases indicate that spatially segregationist utopian desire runs through resort development discourses in Australia and Indonesia. The cases also indicate that attempts to construct utopian resort islands will be contested by local people invested in the waters and adjacent coast targeted for dredging and reclamation. To counter the power of proximity derived from these investments, developers of island utopias may look to the institutional and discursive resources of national spatial utopias but find them unreliable in localized contests over the developments. Indonesian Government support for TWBI was countered by representations of sacred sites and festivals of Indigenous culture around Benoa Bay although not at the internationallyoriented writers festival. NPQ's appeal to patriotic leadership was devastated by 
environmentalists' mobilization around the Australian nativist cry, 'our beaches,' which enabled a more progressive Fremantle Council to come into being that has gone on to replace Australia Day beach fireworks with a festival recognizing Indigenous contributions to community.

\section{Notes}

1. Since its establishment in 2004, Ubud Readers and Writers Festival has grown to attract 25,000 participants annually and become a key venue within the international circuit of literary festivals (MacRae, 2016).

2. The sandbar in Fremantle was the tail of the Yondock ancestral crocodile, placed there by the Waugal serpent guardian of fresh water after their fierce battle in which nearby islands were formed and lands inundated, shaping the current coastline (Moodjar Consultancy, 2016).

\section{References}

Aditjondro, G. J. (1995). Bali, Jakarta's colony: Social and ecological impacts of Jakarta-based conglomerates in Bali's tourism industry (Working Paper No. 58, Asia Research Centre). Perth, WA: Murdoch University.

Cassrels, D. (2014, May 16). Bali crime wave leaves expats bruised and wary. The Australian. Retrieved from https://www.theaustralian.com.au

Cox, S. \& Kerr, T. (2018). One Day in Fremantle: TV representation of this alternative to Australia Day. Coolabah, 24\&25, 229-244.

Corruption and Crime Commission. (2008). Report on the investigation of alleged misconduct concerning Mr Stephen Lee, Mayor of the City of Cockburn. Perth, WA; Author.

D’Anger, J. (2008, July 5). Greens see change. Fremantle Herald, p. 1.

Eco, U. (2015). The book of legendary lands. (A. McEwen, Trans.). London: Hatchette. Fremantle Ports (2013, June). Developing the Rous Head Industrial Park. Fremantle, WA: Fremantle Ports. Retrieved from http://www.fremantleports.com.au

Fremantle Society. (n.d.). Welcome to the Fremantle Society. Retrieved from http://www.fremantlesociety.org.au

Groves, N. (2015, November 3). Ubud writers' festival debates massacre 'that we're not supposed to talk about', The Guardian. Retrieved from http://www.theguardian.com

Hage, G. (2003). Against Paranoid Nationalism: Searching for hope in a sinking society. Annandale, NSW: Pluto Press.

Hartley, J. (1988). A state of excitement: Western Australia and the America's Cup. Cultural Studies, 2(1), 117-126.

Harvey, D. (2000). Spaces of hope. Edinburgh: Edinburgh University Press. 
Hatch, D. (2008, May 29). Grand plan to build six island hubs off north Freo Coast. The West Australian, pp. 1-3.

Hobart, M. (2011). Bali as a brand: A critical approach. Journal of Bali Studies, 1(1), 126.

Kenworthy, J. R. (2006). The eco-city: Ten key transport and planning dimensions for sustainable city development. Environment and Urbanization, 18(1), 67-85.

Kerr, T. (2015). To the beach: Community conservation and its role in 'sustainable development'. Perth, WA: UWA Publishing.

Kerr, T. (2017, Spring/Summer). Roe 8: Politics and power in defence of place. The Architect, pp. 28-31.

Laclau, E. (2005). On populist reason. London: Verso.

Latif. (2014, October 1). Pakar: Revitalisasi berbasis reklamasi perlu dilakukan. Kompas. Retrieved from https://properti.kompas.com

Macbeth, J., Selwood, J. \& Veitch, S. (2012). Paradigm shift or a drop in the ocean? The America's Cup impact on Fremantle, Tourism Geographies, 14(1), 162-182.

MacRae, G. (2005). Negara Ubud: The theatre-state in twenty-first-century Bali. History and Anthropology, 16(4), 393-413.

MacRae, G. (2016). Community and cosmopolitanism in the new Ubud. Annals of Tourism Research, 59(July), 16-29.

Marshall, A. (2011, April 9). Holidays in hell: Bali's ongoing woes, Time. Retrieved from http://time.com

Miéville, C. (2016). Close to shore. In C. Miéville \& U.K. Le Guin (Eds.), Utopia: Thomas More (pp. 3-9). London: Verso.

Mickler, S. (1990). Curators and the colony: Managing the past at Rottnest Island Museum. Continuum: The Australian Journal of Media \& Culture, 3(1), 84-100.

Minca, C. (2000). 'The Bali Syndrome': The explosion and implosion of exotic tourist spaces, Tourism Geographies, 2(4), 389-403.

Moodjar Consultancy (2016). Statements of Significance for the Fremantle Area and Registered Aboriginal Sites - Cantonment Hill, Rocky Bay and Swan River. Fremantle: City of Fremantle.

Neale, T. \& Vincent, E. (2016). Instabilities and inequalities: Relations between Indigenous People and environmentalism in Australia Today. In T. Vincent \& E. Neale (Eds.), Unstable relations: Indigenous People and environmentalism in contemporary Australia, (pp. 1-24). Crawley, WA: UWA Publishing.

North Port Quay (n.d.). FAQs. Perth: North Port Quay. Retrieved from http://www.northportquay.com.au/FAQs/sample-faqs.html

North Port Quay (2008a, June 10). Myth versus fact. Fremantle Gazette, p. 15.

North Port Quay (2008b, June 14). Why can't Western Australia lead the world in sustainable development?. Fremantle Herald, p. 7.

PEMSEA (Partnership in Environmental Management for the Seas of East Asia) \& Bali PMO (Project Management Office). (2004). Southeastern coast of Bali: Initial risk assessment. Quezon City, Philippines: GEF/UNDP/IMO and Bali National ICM Demonstration Project. 
Perera, S. (2009). Australia and the insular imagination: beaches, borders, boats, and bodies. New York: Palgrave Macmillan.

Picard, M. (1996). Bali: Cultural tourism and touristic culture. (D. Darling, Trans.). Singapore: Archipelago Press.

Putra, K. G. D. (2009). Pencemaran lingkungan hidup di Kawasan Teluk Benoa Bali: Perspektif kajian budaya (Unpublished doctoral dissertation). Udayana University, Denpasar, Indonesia.

Schulte Nordholt, H. (2000). Localizing modernity in colonial Bali during the 1930s. Journal of Southeast Asian Studies, 31(1), 101-114.

Strzelecki Group. (2009). About us. Retrieved from www.strzeleckigroup.com.au

Sudiarta, K., Hendrawan, I. G., Putra, K. S., \& Dewantama, I M. I. (2013). Kajian modeling dampak fungsi Teluk Benoa untuk sistem pendukung keputusan (decision support system) dalam jejaring KKP Bali. Denpasar: Conservation International Indonesia. Retrieved from https://nyegaragunung.net/kajianmodeling-dampak-perubahan-fungsi-teluk-benoa-untuk-sistem-pendukungkeputusan-decision-support-system-dalam-jejaring-kkp-bali/

Suastha, R. D. (2016, July 17) Proyek reklamasi benoa akan rusak 70 titik suci, CNN Indonesia. Retrieved from http://cnnidonesia.com

Taylor, R. (2008, June 5). Now's the time to lobby for change. The West Australian, p. 21.

Thiermann, K. (2013, October 16) Bali: Paradise lost?. Huffington Post. Retrieved from https://www.huffingtonpost.com

Tourism WA - Strategy and Research (2018). City of Fremantle visitor factsheet: Three year average - 2015/2016/2017. Fremantle, WA: Tourism Western Australia.

Retrieved from https://www.tourism.wa.gov.au/Publications\%20Library/Research\%20and\%20r eports/2017/LGAs\%20and\%20sub-regions/Fremantle_2017\%20Factsheet.pdf

Tirta Wahana Bali Internasional. (2014). Proposal reklamasi: Revitalisasi Teluk Benoa Bali. Jakarta: PT Tirta Wahana Bali Internasional.

UNESCO. (2010). Australian convict sites. World Heritage. Retrieved from http://whc.unesco.org/en/list/1306

Vickers, A. (2012). Bali: A paradise created (2nd ed). Tokyo, Vermont \& Singapore: Tuttle Publishing.

Warren, C. (1998). Tanah Lot: The cultural and environmental politics of resort development in Bali. In P. Hirsch and C. Warren (Eds.), The Politics of environment in Southeast Asia: Resources and resistance (pp. 229-261). London \& New York: Routledge.

Warren, C. (2009). Off the market? Elusive links in community-based sustainable development initiatives in Bali. In C. Warren and J. McCarthy (Eds.), Community, Environment and Local Governance in Indonesia: Locating the Commonweal (pp. 197-226). London: Routledge.

Warren, C. (2012). Risk and the sacred: Environment, media and public opinion in Bali. Oceania, 82(3), 294-307. 
Warren, C., \& A. Wardana. (2018). Sustaining the unsustainable? Environmental impact assessment and overdevelopment in Bali, Asia Pacific Journal of Environmental Law, 21(2), 101-125.

Wardana, A. (2018) Legal engineering in a contest over space in Bali, Australian Journal of Asian Law, 19(1), 1-12.

Wardana, A. (2019). Contemporary Bali: Contested space and governance. Singapore: Palgrave Macmillan.

Westport (2018). Westport: What we have found so far. Perth: Government of Western Australia. Retrieved from file:///C:/Users/242162f/Documents/Kwinana\%20Outer\%20Harbour\%20Plan/W estport_WWHFSF_Report_2018.pdf

Whish-Wilson, D. (2017, March 2). The WA state election could end one of the country's most controversial infrastructure projects. The Monthly. Retrieved from https://www.themonthly.com.au 